\title{
Ni-smectitic ore behaviour in the Caron process
}

Eliana S. Mano ${ }^{1 *}$, Laurent Caner ${ }^{2}$, Sabine Petit ${ }^{2}$, Arthur P. Chaves ${ }^{1}$ and André S. Mexias $^{3}$

${ }^{1}$ Escola Politécnica - São Paulo University - Departament of Mining and Petroleum Engineering. Av. Prof. Mello Moraes 2.373 - 05508-900, São Paulo Brazil.ellimano@hotmail.com

${ }^{2}$ Institut de Chimie des Milieux et Matériaux de Poitiers, IC2MP, UMR 7285 Université de Poitiers, CNRS - Poitiers, France

${ }^{3}$ Universidade Federal do Rio Grande do Sul, Instituto de Geociências UFRGS

\section{Abstract}

Niquelândia is a nickel-lateritic ore deposit located in the State of Goiás, Brazil. This deposit is a nickel-lateritic orebodies in Brazil and contains both oxidized and silicate ores. In the oxidized ores, nickel is essentially associated with goethite, while in the silicate ores, it is associated with clay minerals, especially smectites. Two types of smectites were found: a Ni-Mg-rich trioctahedral and an Al-Fe-rich dioctahedral structure.

Nickel was produced at Niquelândia by the Caron process, a reduction roasting operation followed by ammoniacal leaching.

Usually, the Caron process is able to extracts over $90 \%$ of $\mathrm{Ni}$ from the oxidized ore and less than $60-70 \%$ from the silicate ore. At Niquelândia the nickel recoveries varied from 70 to $75 \%$ of nickel from the Run of Mine (oxidized+silicate ores).

A detailed study of the mineralogy from the silicate ore residues of the Caron process was conducted in order to find out why nickel extraction is not properly performed in this type of ore. The results revealed: 1 ) higher nickel extraction is assigned to iron-rich dioctahedral smectites and 2) lower nickel extraction is assigned to nickel-rich trioctahedral smectites; finally, 3) the low Fe content of $\mathrm{Ni}$ -

\footnotetext{
1* Corresponding author at: elli_mano@hotmail.com
} 
rich trioctahedral smectites does not allow forming Ni-Fe phases which can be dissolved by the ammoniacal leaching.

Keywords: nickel lateritic ores, Caron process, Niquelândia, mineralogical characterization, mineral processing, clay minerals, smectite.

- In the silicate ore, nickel is associated with di and trioctahedral smectites

- Residues from roasting and ammoniacal leaching of Ni-silicate ore were studied

- Fe-Ni phases were not formed from roasted residues of trioctahedral smectite

- High Ni recovery was noted for Fe-rich dioctahedral smectites

\section{Introduction}

Nickel is processed mainly from sulphide ores and secondly from lateritic ores (Boldt, 1967; Trescases et al., 1981; Bunjaku, 2013). However, in Brazil, the latter represents the most common source of nickel. Lateritic deposits are composed of oxidized (limonite) and/or silicate ores (Boldt, 1967; Oliveira et al., 1992), both formed from the weathering of basic and/or ultramafic rocks (e.g., dunites). In the oxidized type, nickel is mainly associated with goethite, spinels and asbolane. By contrast, in the silicate ore, nickel is present in the structures of clay minerals such as smectite, serpentine, vermiculite, talc, and chlorite.

The Niquelândia deposit was composed by both oxidized and silicate ores (Mano et al., 2014). In this deposit, the formation of the lateritic ore is related to intense weathering processes under a seasonally humid tropical climate from peridotites, dunites and pyroxenites which have been altered into clay minerals and goethite. During weathering Ni-Mg-rich trioctahedral smectites $\left((\mathrm{Mg}, \mathrm{Ni})_{\times} \mathrm{Si}_{4}[\mathrm{Mg}, \mathrm{Ni}]\right]_{3-\mathrm{x}} \cdot{ }_{\times} \mathrm{O}_{10}$ $[\mathrm{OH}]_{2}$ ) were formed due to the low contents of aluminium of the ultramafic rocks (Colin et al., 1990; Petit et al., 2002; Mano et al., 2014); and with the increase of 
the weathering, nickel and magnesium were leached, forming Al-Fe-dioctahedral rich smectites $\left(\left(\mathrm{Mg}, \mathrm{Ni}_{\times} \mathrm{Si}_{4}[\mathrm{Fe}, \mathrm{Al}, \mathrm{Mg}, \mathrm{Ni}]\right]_{2-x} \mathrm{O}_{10}[\mathrm{OH}]_{2}\right)$ with lower nickel grades (Gaudin et al., 2004; Christidis and Mitsis, 2006). The formula above exhibits a square as vacancy, due to the chemical substitutions (divalent cations) in the octahedral layers achieve electrical neutrality (Moore and Reynolds, 1997).

Either pyrometallurgical or hydrometallurgical methods can be used to extract nickel from the lateritic ores, depending on their mineralogical characteristics. Canterford (1975); Dalvi et al., (2004) and Rice (2016) noticed that magnesiumrich ores are not suited to acid hydrometallurgical routes due to the high consumption of sulphuric acid by magnesium. Conversely, lateritic ores with a low $\mathrm{SiO}_{2} / \mathrm{MgO}$ ratio and low iron content are better suited to pyrometallurgical routes, to produce ferronickel phases (Canterford, 1975; De Graaf, 1980; Diaz et al., 1988; Dalvi et al., 2004). Even though Diaz et al. (1988) stated that magnesium-rich ores are suited to Caron processing, De Graaf $(1979 ; 1980)$ and Rhamdhani, et al. (2009a) did not obtain over $65 \%$ nickel recovery for the silicate ores processed by the Caron process, even in a reducing environment, using different gases (hydrogen, $\mathrm{CO}_{2} / \mathrm{CO}$ ratio, $\mathrm{H}_{2} \mathrm{O} / \mathrm{H}_{2}$, and others). However, for the limonitic ores, the Caron process works well, with nickel extractions over $90 \%$ (De Graaf, 1979).

Despite this, the Caron process was applied at Niquelândia in 1980; the initial run of mine (feed) was altered through the years, increasing the silicate proportion and decreasing the nickel yields. The Niquelândia run of mine was established with $4 \%$ of $\mathrm{MgO}, 26 \%$ of $\mathrm{SiO}_{2}, 8 \%$ of $\mathrm{Al}_{2} \mathrm{O}_{3}, 25 \%$ of $\mathrm{Fe}$ and $1.5 \%$ of $\mathrm{Ni}$; however, nickel extraction did never exceed $75 \%$. Thereby, in order to understand the lower nickel yields, specially assigned to silicate ore, X-ray diffraction, scanning 
electron microscopy, coupled to X-ray dispersion energy analysis, medium infrared spectroscopy and thermogravimetric and differential thermal analyses were performed, from the silicate ore residues obtained by the Caron process (roasting+leaching residues) applied to Niquelândia processing.

Five silicate samples, with different nickel, iron and magnesium amounts, previously studied by Mano et al. (2014), were selected.

Table 1 shows all the minerals mentioned in this study.

Table 1 - Minerals relevant in this study

\begin{tabular}{|c|c|c|c|}
\hline minerals & formulae & minerals & formulae \\
\hline \multirow[t]{2}{*}{ smectite } & $\begin{array}{c}(\mathrm{Mg}, \mathrm{Ni})_{\times} \mathrm{Si}_{4}[\mathrm{Mg}, \mathrm{Ni}]_{3-\mathrm{x}} \cdot{ }_{\times} \mathrm{O}_{10} \\
{[\mathrm{OH}]_{2}}\end{array}$ & amphibole & $\mathrm{Ca}_{2}\left(\mathrm{Mg}, \mathrm{Fe}^{++}\right)_{5} \mathrm{Si}_{8} \mathrm{O}_{22}(\mathrm{OH})_{2}$ \\
\hline & $\begin{array}{c}(\mathrm{Mg}, \mathrm{Ni})_{\times} \mathrm{Si}_{4}[\mathrm{Fe}, \mathrm{Al}, \mathrm{Mg}, \mathrm{Ni}]_{2-x} \\
\mathrm{O}_{10}[\mathrm{OH}]_{2}\end{array}$ & & $\mathrm{Ca}_{2}\left[\mathrm{Mg}_{4}\left(\mathrm{Al}, \mathrm{Fe}^{+++}\right)\right] \mathrm{Si}_{7} \mathrm{AlO}_{22}(\mathrm{OH})_{2}$ \\
\hline talc & $(\mathrm{Ni}, \mathrm{Mg})_{3} \mathrm{Si}_{4} \mathrm{O}_{10}(\mathrm{OH})_{2}$ & & {[] $\mathrm{Ca}_{2} \mathrm{Mg}_{5} \mathrm{Si}_{8} \mathrm{O}_{22}(\mathrm{OH})_{2}$} \\
\hline \multirow[t]{2}{*}{ pyroxene } & $\mathrm{Mg}_{2} \mathrm{Si}_{2} \mathrm{O}_{6}$ & Olivine & $\mathrm{Mg}_{2} \mathrm{SiO}_{4}$ \\
\hline & $\mathrm{CaMgSi}_{2} \mathrm{O}_{6}$ & & $\mathrm{Fe}^{++}{ }_{2} \mathrm{SiO}_{4}$ \\
\hline \multirow[t]{3}{*}{ serpentine } & $\mathrm{Mg}_{3} \mathrm{Si}_{2} \mathrm{O}_{5}(\mathrm{OH})_{4}$ & magnetite & $\mathrm{Fe}^{++} \mathrm{Fe}^{+++}{ }_{2} \mathrm{O}_{4}$ \\
\hline & $\left(\mathrm{Ni}, \mathrm{Mg}, \mathrm{Fe}^{++}\right)_{2} \mathrm{Al}(\mathrm{SiAl}) \mathrm{O}_{5}(\mathrm{OH})_{4}$ & spinel & $\mathrm{MgAl}_{2} \mathrm{O}_{4}$ \\
\hline & $\left(\mathrm{Mg}, \mathrm{Fe}^{++}\right)_{3} \mathrm{Si}_{2} \mathrm{O}_{5}(\mathrm{OH})_{4}$ & hematite & $\mathrm{Fe}_{2} \mathrm{O}_{3}$ \\
\hline vermiculite & $\mathrm{Mg}_{1.8} \mathrm{Fe}^{2+}{ }_{0.9} \mathrm{Al}_{4.3} \mathrm{SiO}_{10}(\mathrm{OH})_{2} \bullet 4\left(\mathrm{H}_{2} \mathrm{O}\right)$ & goethite & $\begin{array}{c}\mathrm{FeO}(\mathrm{OH}) \\
\mathrm{Ni}_{0.3} \mathrm{Co}_{0.1} \mathrm{Ca}_{0.1} \mathrm{Mn}^{2+}{ }_{1.5} \mathrm{O}_{1.5}\end{array}$ \\
\hline chlorite & $\mathrm{Mg}_{3.75} \mathrm{Fe}^{2+}{ }_{1.25} \mathrm{Si}_{3} \mathrm{Al}_{2} \mathrm{O}_{10}(\mathrm{OH})_{8}$ & asbolane & $(\mathrm{OH})_{2} \cdot 0.6\left(\mathrm{H}_{2} \mathrm{O}\right)$ \\
\hline quartz & $\mathrm{SiO}_{2}$ & $\begin{array}{l}\mathrm{Fe}-\mathrm{Ni} \\
\text { phase }\end{array}$ & $\mathrm{FeNi}_{3}$ \\
\hline
\end{tabular}

\section{Previous results of the characterized samples}

Mano et al. (2014) showed that the silicate ores from the Niquelândia deposit contained Ni-bearing clay minerals, quartz, iron and/or manganese oxides/hydroxides, pyroxene and olivine in minor quantities. The chemical compositions of the bulk samples measured by inductively coupled plasma (ICPAES) are given in Table 2, and energy dispersion X-ray spectroscopy 
microanalyses performed by scanning electron microscopy (SEM/EDX) are plotted in Figure 1.

These results showed that in the silicate ore, nickel is essentially associated with two types of smectites (Figures 1 and 2) present in the clay fraction $(<2 \mu \mathrm{m})$, a Fe-rich dioctahedral one (sample ASL-15) and a Ni-rich trioctahedral one (sample AS-ANi3).

Sample AS-ANi3 had a high nickel content (23.4\%), and $\mathrm{Ni}^{2+}$ was the dominant divalent cation in octahedral sheets (magnesium-nickel stevensite end-member). In turn, in sample ASL-15, with a low nickel content, $\mathrm{Fe}^{3+}$ was the dominant octahedral trivalent cation (iron-nickel montmorillonite end-member) (Mano et al., 2014). The samples VSL1A, ASL-AN3, AS-BNi2, CSL-G8 and VSL-R2 were mixtures of these two end-members and exhibited intermediate properties, as shown in Figure 1.

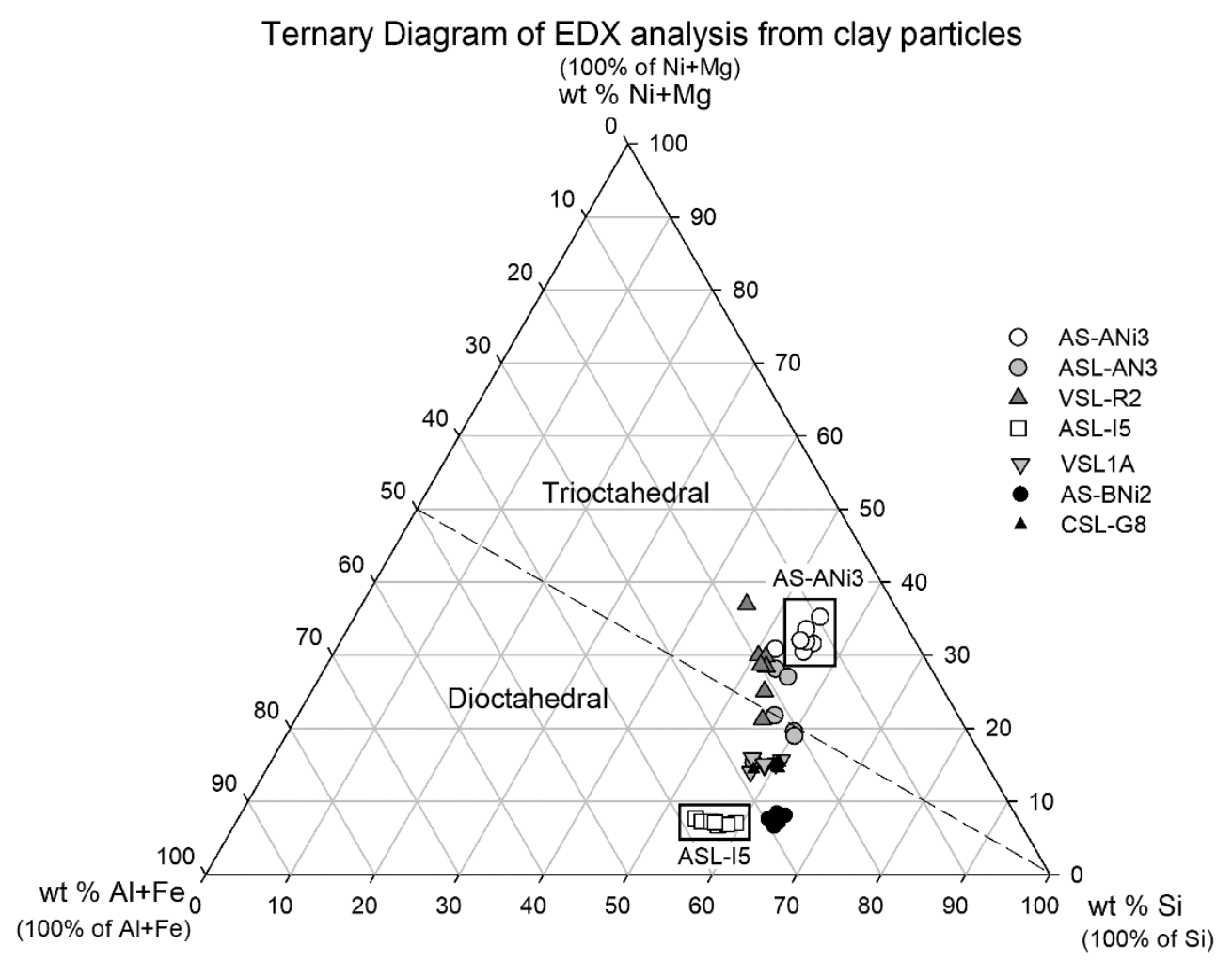

Figure 1 - EDX analyses showing smectite compositions varying from di to trioctahedral group members. Modified from Mano et al. (2014). Data points represent compositions in Table 2. 


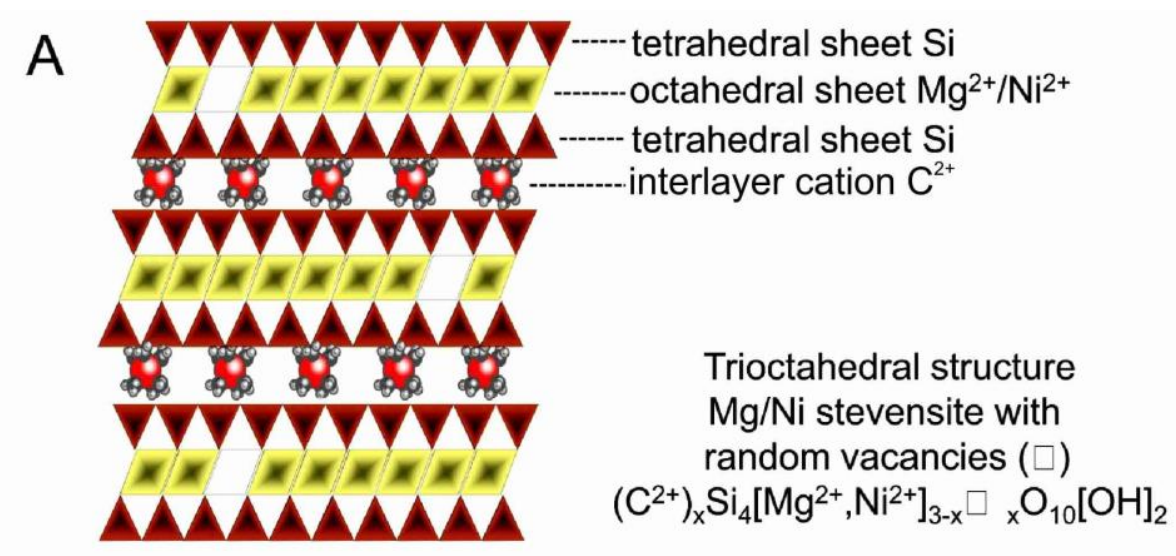

B $\quad \nabla \nabla \nabla \nabla \nabla \nabla \nabla--$--tetrahedral sheet $\mathrm{Si}$

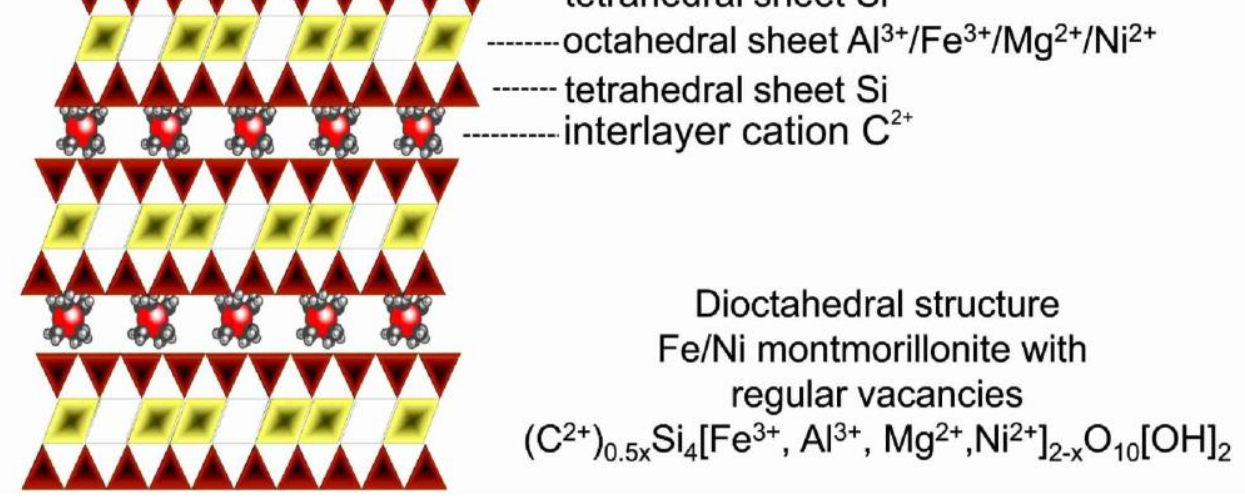

Figure 2 - (A) Tri and (B) Dioctahedral structures of the smectites from Niquelândia (see Mano et al., 2014).

Table 2 - Chemical analyses results from ICP-AES for all samples (Mano et al., 2014).

\begin{tabular}{ccccccccccc}
\hline Samples & & \multicolumn{8}{c}{ Chemical results $(\mathrm{wt} \%)$} \\
& $\mathrm{NiO}$ & $\mathrm{Fe}_{2} \mathrm{O}_{3}$ & $\mathrm{CoO}$ & $\mathrm{CuO}$ & $\mathrm{MnO}$ & $\mathrm{Cr}_{2} \mathrm{O}_{3}$ & $\mathrm{Al}_{2} \mathrm{O}_{3}$ & $\mathrm{MgO}$ & $\mathrm{SiO}_{2}$ & $\mathrm{LOI}$ \\
\hline AS-ANi3 & 23.4 & 5.23 & 0.45 & 0.8 & 0.12 & 1.30 & 2.45 & 7.44 & 39.9 & 6.82 \\
ASL-15 & 1.16 & 32.4 & 0.05 & 0.19 & 0.56 & 1.96 & 4.76 & 5.07 & 44.6 & 6.68 \\
VSL1A & 9.43 & 14.3 & 0.05 & 0.21 & 0.3 & 2.39 & 8.52 & 7.55 & 44.1 & 7.91 \\
ASL-AN3 & 7.75 & 13.4 & 0.02 & 0.23 & 0.3 & 1.33 & 5.07 & 12.4 & 40.1 & 5.53 \\
CSL-G8 & 2.08 & 15.3 & 0.03 & 0.13 & 0.23 & 1.39 & 5.07 & 10.5 & 50.7 & - \\
AS-BNi2 & 2.11 & 17.7 & 0.08 & 0.24 & 0.52 & $\mathrm{ND}$ & 3.95 & 4.87 & 51.0 & 8.45 \\
VSL-R2 & 4.74 & 10.1 & 0.02 & 0.04 & 0.22 & 1.08 & 3.93 & 19.1 & 35.1 & 3.71 \\
\hline
\end{tabular}

\section{Materials and Methods}

At Niquelândia, the nickel was extracted by the Caron process, which combines a reduction roasting step at $770^{\circ} \mathrm{C}$, conducted in a Nichols Herreshoff multiple hearth furnace, followed by an ammoniacal leaching step. Thereby, this study was conducted on the residues obtained by the Caron process from silicate ore to investigate mineralogical transformations occurring during the processing. Five 
samples studied by Mano et al. (2014) were selected based on their chemical compositions and nickel extractions: AS-ANi3, ASL-15, VSL1A, ASL-AN3 and VSL-R2 (Table 1 and Figure 1).

Reduction roasting and leaching simulations were carried out at the Niquelândia laboratory using the mining company protocol based on the procedure applied by De Graaf (1979); Valix and Cheung (2002) and Rhamdhani et al. (2009b). The reduction roasting process was performed in a small tube furnace, the dimensions of which are $573 \mathrm{~mm}$ (width), $663 \mathrm{~mm}$ (height) and $455 \mathrm{~mm}$ (depth). A reducing atmosphere was used in the furnace all throughout the experiment by injecting a mixture of $10.5 \%$ of $\mathrm{CO}, 8 \%$ of $\mathrm{CO}_{2}, 10 \%$ of $\mathrm{H}_{2}$ and $71.5 \%$ of $\mathrm{N}_{2}$. This atmosphere is similar to that of the Nichols Herreshoff multiple hearth furnace used in the processing of ores.

Three reduction temperatures were tested: $550^{\circ} \mathrm{C}$, which corresponds to the dehydroxylation temperature of different dioctahedral clay minerals; $770^{\circ} \mathrm{C}$, which corresponds to the Caron process temperature; and, finally, $900^{\circ} \mathrm{C}$, the supposed temperature at which new mineral phases start to form (De Graaf, 1980).

A mixture of $0.756 \mathrm{~g}$ of petroleum coke and $1.47 \mathrm{~g}$ of fuel oil was added to $100 \mathrm{~g}$ of the bulk sample (the silicate ore $<10 \mu \mathrm{m}$ size fraction) and introduced into the furnace at a temperature of $450^{\circ} \mathrm{C}$ under a $\mathrm{N}_{2}$ atmosphere. Afterwards, the reducing gas mixture was connected, the $\mathrm{N}_{2}$ flux was interrupted and the temperature of the furnace was increased to $550^{\circ} \mathrm{C}$, at which the sample remained for 40 min. Finally, the reductant gas mixture was unplugged, and the $\mathrm{N}_{2}$ flow was reconnected.

The sample temperature decreased naturally to $450^{\circ} \mathrm{C}$, and then, the temperature was forced to decrease to $60^{\circ} \mathrm{C}$ with a ventilator; there was no interruption of the 
$\mathrm{N}_{2}$ flux during cooling, used to prevent the re-oxidation of the samples. At $60^{\circ} \mathrm{C}$, the sample was removed from the furnace and introduced into a container with water to prevent the oxidation of the metals. All of the above procedure was repeated for the experiments at reduction temperatures of $770^{\circ} \mathrm{C}$ and $900^{\circ} \mathrm{C}$.

The leaching process (Yabulu procedure) was performed using a solution of ammonium carbonate and free ammonia with an approximate molar ratio of about $\left.1: 2\left(\left(\mathrm{NH}_{4}\right)_{2} \mathrm{CO}_{3}\right)+2 \mathrm{NH} 3\right)$; prepared from 90 to $100 \mathrm{~g} / \mathrm{L}$ of $\mathrm{NH}_{3}$ and 80 to $85 \mathrm{~g} / \mathrm{L}$ of $\mathrm{CO}_{2}$. In the steel reactor, approximately $100 \mathrm{~mL}$ of the roasted material was added to $3000 \mathrm{~mL}$ of ammoniacal solution. The reactor was closed and the mixture was stirred with air injection of $120 \mathrm{~L} / \mathrm{min}$. The $\mathrm{pH}$ of the experiment was controlled between 9.5 and 10.5 and the shaker was set to $280 \mathrm{rpm}$ (vertical shaker rod) for 2 hours; the temperature was not higher than $50^{\circ} \mathrm{C}$. At this time, the shaker and the compressed air were turned off and the solution was left quiescent for 1 hour. Finally, the leached residue was filtered and washed in an ammonia solution and then with demineralized water. The residue and the leached solution were analysed by ICP-AES. X-ray diffraction (XRD) and scanning electron microscopy, coupled with an energy dispersion X-ray spectroscopy microanalysis (SEM/EDX) and Fourier Transform Infrared Spectroscopy (FTIR) were used to determine the mineral phase transformations that occurred during the reduction roasting and the leaching steps.

The XRD patterns were recorded on a Bruker D8 Advance instrument with the following parameters: Cu Ka radiation - $40 \mathrm{kV}$ and $40 \mathrm{~mA}$ - Lynxeye detector, from 3 to $65^{\circ} 2 \theta$, with steps of $0.02^{\circ} 2 \theta$ and a counting time per step of $115 \mathrm{~s}$. The mid-infrared spectra (MIR) from the residual material were obtained from pressed $\mathrm{KBr}$ pellets using a Nicolet Magna-IR 760 spectrometer in the range 400- 
$4000 \mathrm{~cm}^{-1}$ with a $4 \mathrm{~cm}^{-1}$ resolution. The pellets were prepared following the procedure described by Baron and Petit (2016).

Two scanning electron microscopes (SEM) coupled with EDX microanalysis systems were used to investigate the association of nickel with the different minerals in the reduction and leaching products: a LEO-Stereoscan 440/INCA Oxford instrument operating at $20 \mathrm{kV}$ and $20 \mathrm{~mA}$, with a silicon drift detector (SDD) at the Universidade de São Paulo and a JEOL JSM-5600 LV instrument coupled with a BRUKER X-Flash 4010 EDS spectrometer at the Université de Poitiers.

Thermogravimetric and differential thermal analyses (TG and DTA) were conducted to check the minerals behaviour during the heating process. These analyses were performed using a Du Pont SDT2960 model at the Universidade Federal de Ouro Preto (Minas Gerais - Brazil). The data were obtained from the bulk samples from $25^{\circ} \mathrm{C}$ to $1,000^{\circ} \mathrm{C}$ with a heating rate of $10^{\circ} \mathrm{C} / \mathrm{min}$ under air flow of $100 \mathrm{~mL} / \mathrm{min}$.

\section{Results}

\subsection{XRD results}

The reduction roasting step is the most important part of the Caron process, being responsible for transforming nickel bearing minerals (i.e. clay minerals, spinels and goethite) to phases more suitable for the ammoniacal leaching, such as ironnickel metallic phases.

The increase of the temperature above $550^{\circ} \mathrm{C}$, during the reduction roasting stage, transformed clay minerals (mainly smectites) and goethite into talc, olivines, pyroxenes, amphiboles, spinels and hematite (Figures 3 and 4); however, samples ASL-15, AS-ANi3, ASL-AN3 and VSL-R2, already contained 
spinels and pyroxenes before the reduction roasting step. For sample ASL-15, the incremental increase of the temperature $\left(>550^{\circ} \mathrm{C}\right)$ transformed smectites into talcs, which, in turn, formed pyroxene and olivine at $900^{\circ} \mathrm{C}$. In this sample, new spinel phases and Fe-Ni alloy had already formed at $770^{\circ} \mathrm{C}$.

Sample AS-ANi3, which was initially composed of smectites, talc, pyroxene and spinels, continued to exhibit talc peaks at $770^{\circ} \mathrm{C}$, as explained by Ptáček et al. (2013), which showed that talc dehydroxylation occurs at temperatures close to $900^{\circ} \mathrm{C}$ to form pyroxenes. A minor content of spinels was observed at $770^{\circ} \mathrm{C}$; however, no Fe-Ni alloy was noted; actually, in this sample, no metallic phases were detected, even at high temperatures (Figure 3).

For samples VSL1A, ASL-AN3 and VSL-R2, with different proportions of di and trioctahedral smectites, different behaviours were noted, based on the initial mineral phases. Sample VSL1A, which was composed essentially of smectites and a minor amount of spinel, formed a talc, pyroxene and an Fe-Ni alloy at $770^{\circ} \mathrm{C}$. At $900^{\circ} \mathrm{C}$, talc disappeared and only pyroxene, spinels and Fe-Ni alloy were noted. Sample ASL-AN3, revealed smectites, talc, pyroxenes, spinels and hematite in the bulk sample, formed a small amphibole content at $770^{\circ} \mathrm{C}$. Talc and pyroxene remained at this temperature; olivine and Fe-Ni alloy had been formed. Finally, sample VSL-R2, consisted essentially of pyroxenes and secondarily of smectites and spinels; after the reduction roasting stage $\left(770^{\circ} \mathrm{C}\right)$, in addition to pyroxenes and spinels, small quantities of amphibole and $\mathrm{Fe}-\mathrm{Ni}$ alloy were formed.

Figure 5 shows the XRD patterns for the reduced and leached products (VSL1A, ASL-AN3 and VSL-R2). The black lines show the phases detected after the roasting stage and the grey lines, after the leaching stage. Sample VSL1A, which 
formed a Fe-Ni alloy at $770^{\circ} \mathrm{C}$, exhibited a poor nickel extraction, as discussed later. Conversely, sample VSL-R2, which exhibited a good nickel extraction, indicated a significant leached proportion of Fe-Ni alloy (grey line); moreover, spinels and Fe-phase were also leached. Sample ASL-AN3 for which Fe-Ni alloy was also formed suggested a nickel extraction proportion smaller than sample VSL-R2.

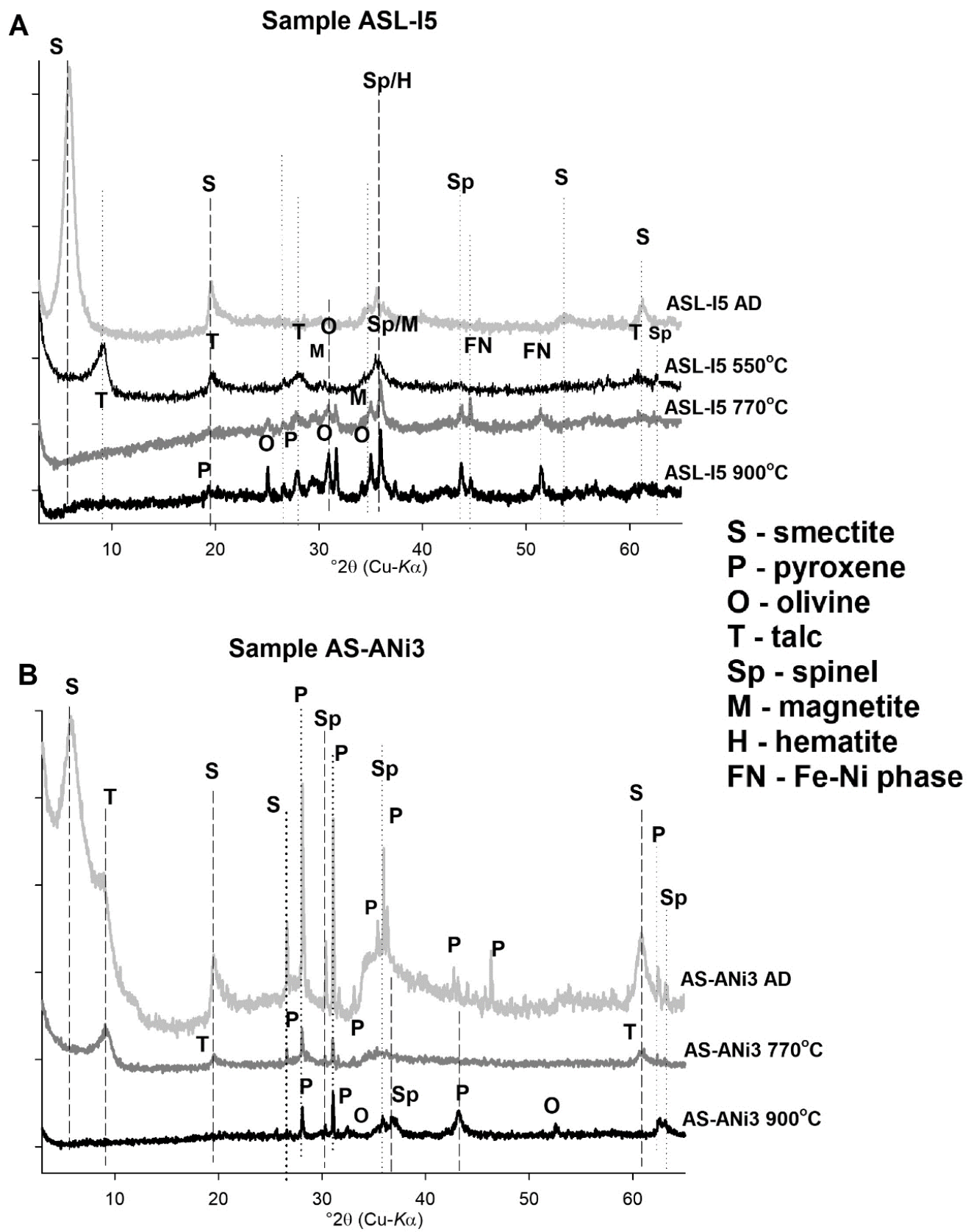

Figure 3 - XRD patterns for samples: a) ASL-I5 and b) AS-ANi3, before and after the reduction roasting step. 
A
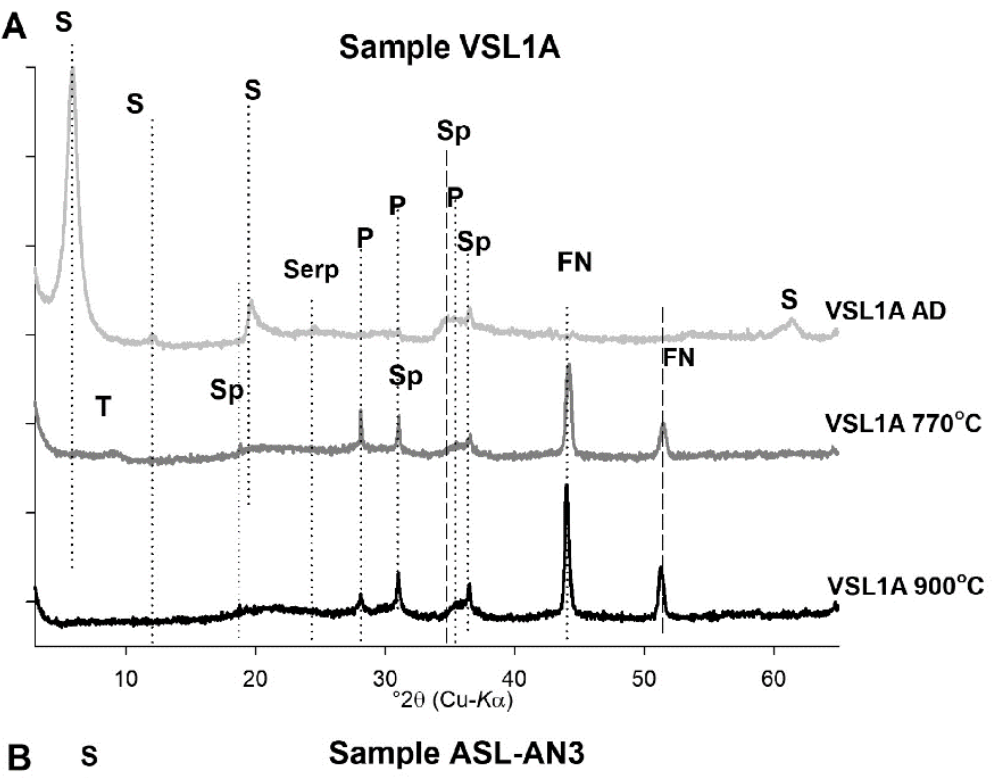

S- smectite Serp - serpentine A- amphibole

B $\mathrm{s}$

T- talc

P- pyroxene

O- olivine

Sp-spinel

M- magnetite

$\mathrm{H}$ - hematite

FN- Fe-Ni phase

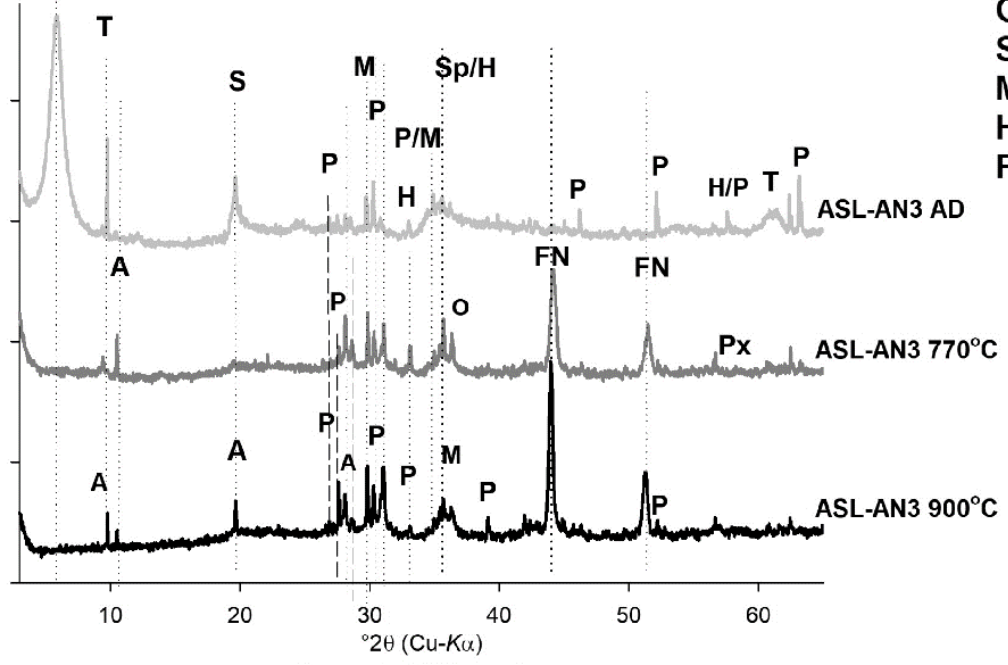

Sample VSL-R2

C

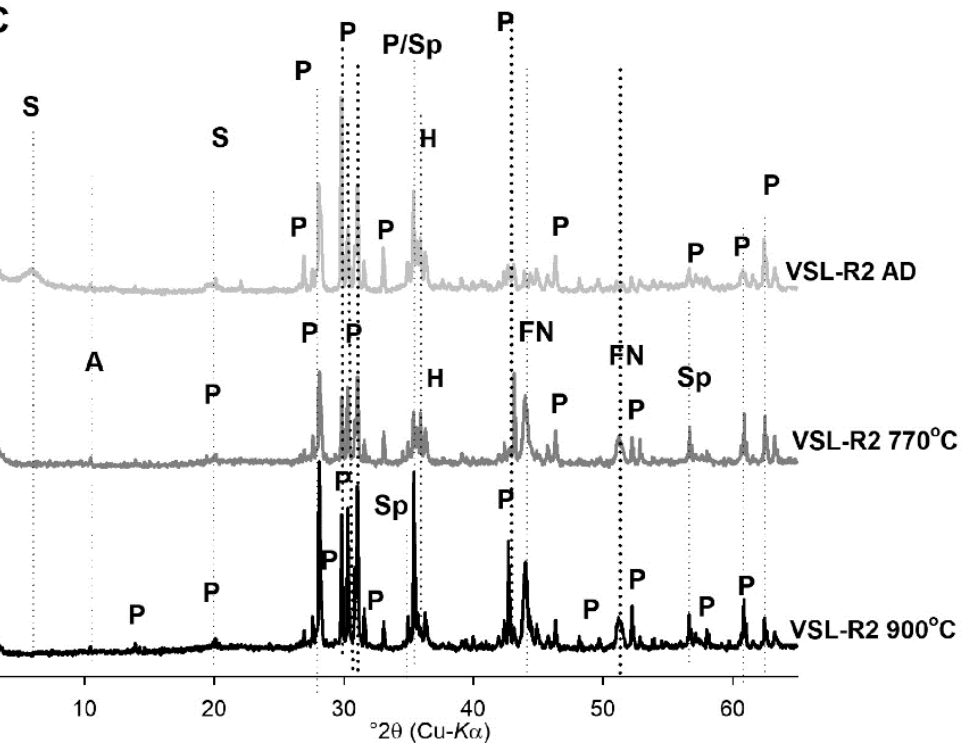

Figure 4 - XRD patterns for samples: a) VSL-1A, b) ASL-AN3 and c) VSL-R2, before and after the reduction roasting step. 


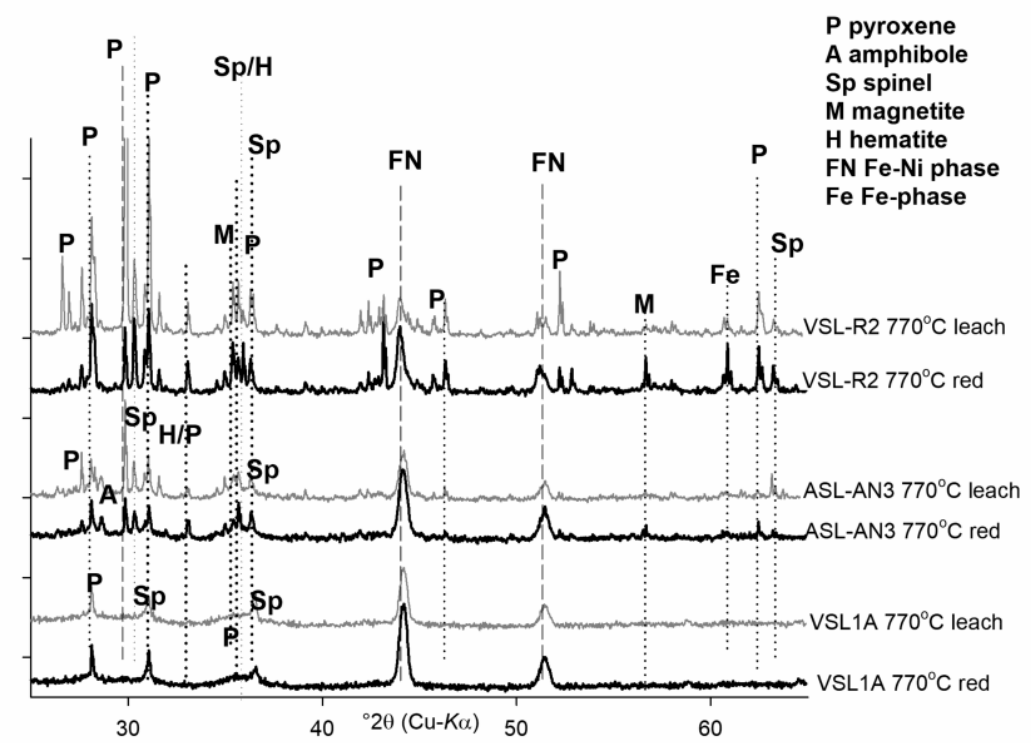

Figure 5 - XRD patterns for samples: a) VSL-1A, b) ASL-AN3 and c) VSL-R2, heated and leached products. Iron phases were leached.

\subsection{DTA and TGA analyses}

Thermal gravimetric (TGA) and differential thermal analyses (DTA) were conducted to determine the dehydroxylation temperature for samples AS-ANi3 and ASL-15 (Figures 6 and 7) and to confirm the main mineral changes observed by X-ray diffraction.

The peak of the DTA curves at $74-82^{\circ} \mathrm{C}$ is related to the water absorbed by the smectites. For sample ASL-15 (Fe-rich dioctahedral smectite), the dehydroxylation reaction occurred at $442^{\circ} \mathrm{C}$ (Figure 6), which is in agreement with clay mineral changes observed in the XRD patterns (Figure 3) at low temperatures $\left(<550^{\circ} \mathrm{C}\right)$. Low temperatures of dehydroxylation for Fe-rich smectites were also observed by Frost et al. (2002) for nontronites from Garfield (USA) and Uley (Australia). Indeed, Brigatti (1983) showed that the temperature of dehydroxylation of smectite depends on the iron content; and it is well known that a higher iron content induces lower dehydroxylation temperatures (Arab et al., 2015). Sample AS-ANi3 (Fe-poor smectite), in turn, revealed a 
dehydroxylation peak at $648^{\circ} \mathrm{C}$ (Figure 7) attributed to the dehydroxylation of $\mathrm{Fe}$ poor smectites. Christidis and Mitsis (2006) and Ptáček et al. (2013) reported that talc transformed to pyroxene at approximately $850^{\circ} \mathrm{C}$. The peak at $882^{\circ} \mathrm{C}$ is then attributed into the formation of pyroxenes for sample AS-ANi3, in agreement with the presence of this phase on the XRD patterns (Figure 3).

The dehydroxylation temperature of goethite occurs at $300^{\circ} \mathrm{C}$, as observed for the TGA curve for sample ASL-I5 (Figure 6) and as described by several authors (Chander and Sharma, 1981; Cornell and Schwertmann, 2003; O'Connor et al., 2006; Elliott et al., 2016).

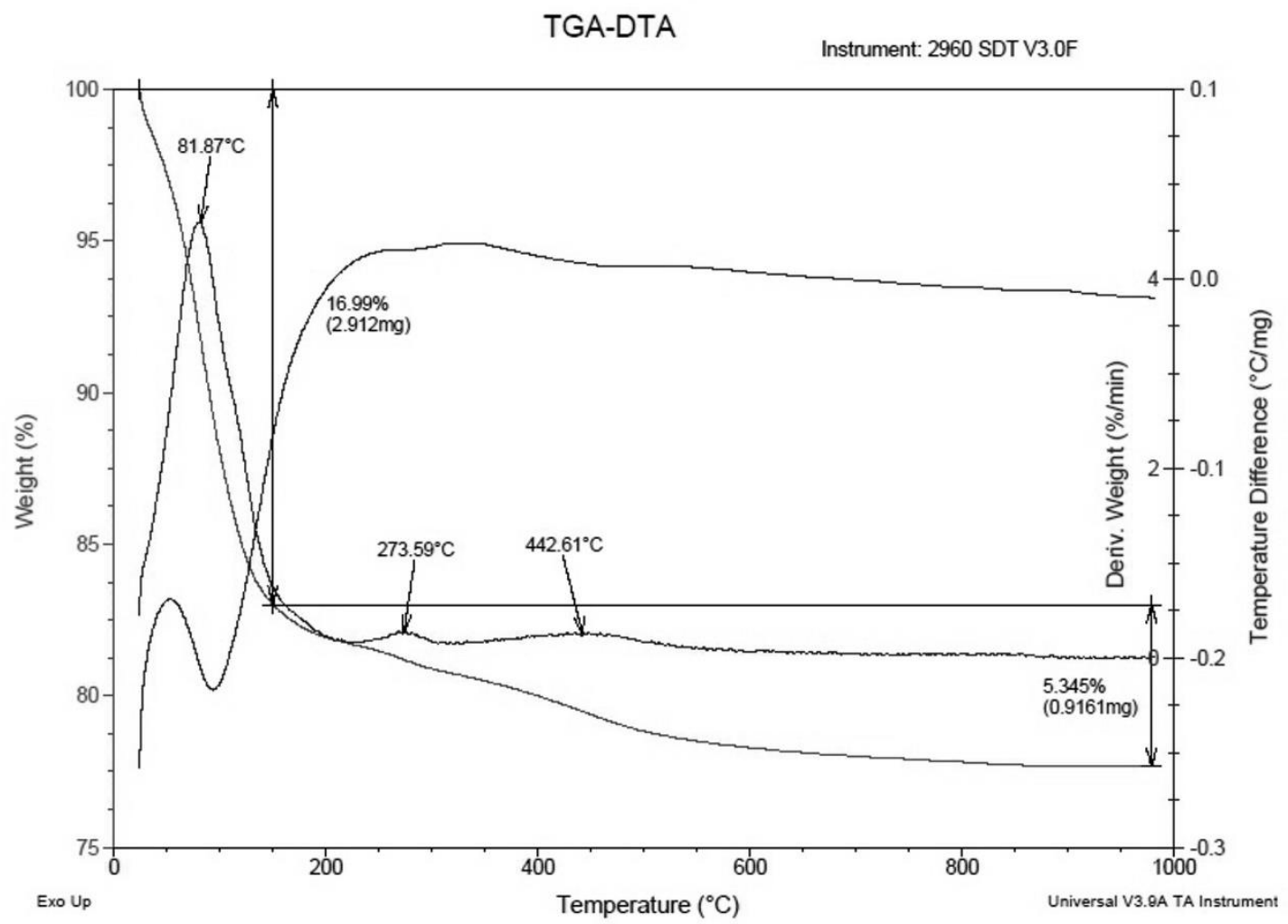

Figure 6 - DTA and TGA curves for sample ASL-15. 


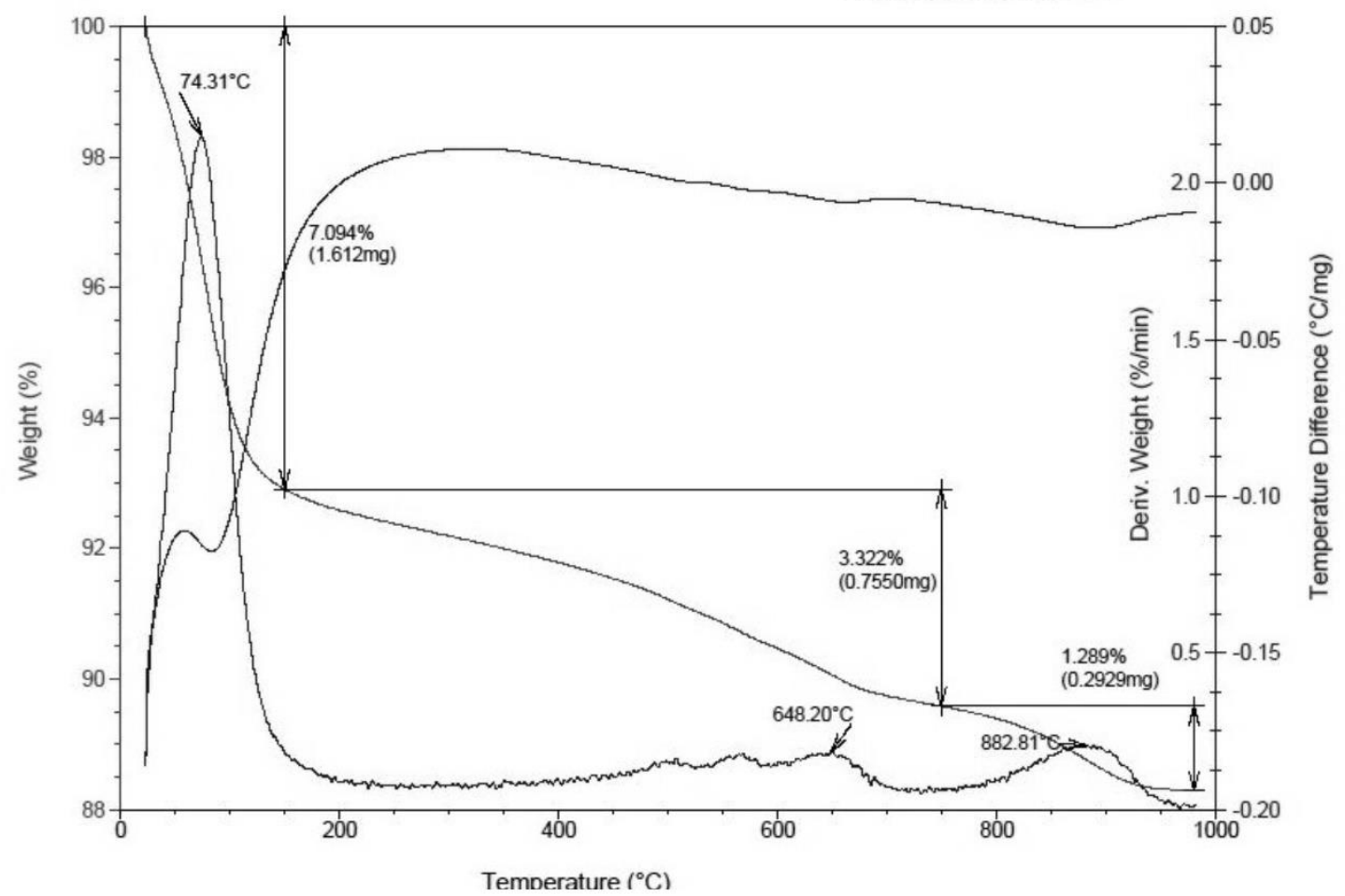

Figure 7 - DTA and TGA curves for sample AS-ANi3.

\subsection{Scanning electron microscopy and EDX analyses}

Textural aspects were observed by SEM (Figure 8). Clay mineral structures were preserved (Figure $8 \mathrm{~A}$ ) even after roasting at high temperatures; features arising from dehydroxylation were also observed (Figure $8 \mathrm{C}$ and D). Figure $8 \mathrm{C}$ exhibits a thin iron crust covering an aluminium silicate particle. Figures $8 \mathrm{~B}$ and $8 \mathrm{D}$ show acicular crystals and nickel-cobalt alloy droplets trapped within the silicate particles. The EDX analyses coupled to the SEM from the leach residues revealed that iron and nickel are hosted within the silicate or spinel grains. Valix and Cheung (2002) suggested that nickel incorporated into the magnesium silicate phase is transformed during reduction roasting into forsterite, which is unsuitable for ammoniacal leaching. 


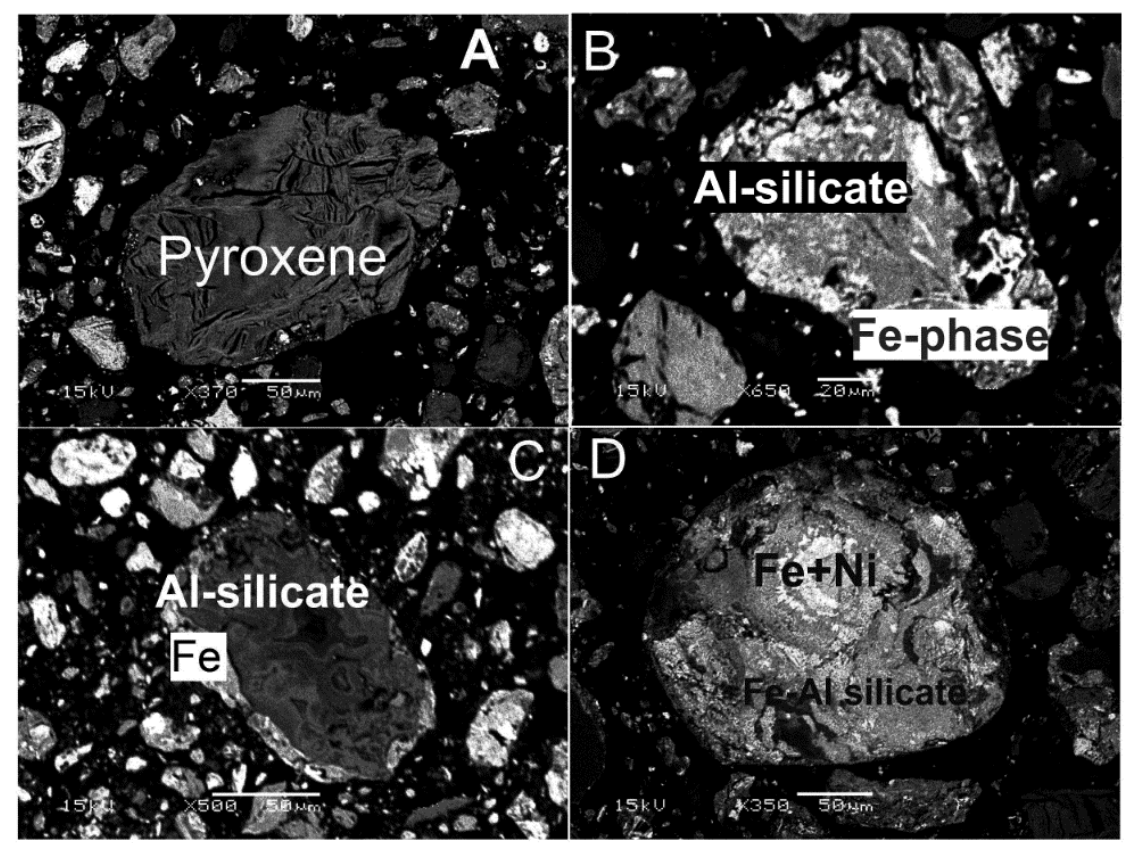

Figure 8 - SEM/BSE images, sample ASL-AN3, after the reduction roasting step. A- pyroxene particle which retains a clay mineral structure. B- Iron oxide was observed in the residue product of the reduction step. C- Iron migrates toward the particle surface after the reduction step. D- metals, such as iron and nickel, trapped inside particles.

\subsection{FTIR spectroscopy}

Table 3 summarizes the results from FTIR, and Figure 9 exhibits the medium infra-red spectra (MIR) for the bulk samples. The Figure 10 presents the MIR for AS-ANi3 sample after reduction step.

Table 3 - FTIR bands observed and their attribution for Ni-Fe smectites

\begin{tabular}{|c|c|c|}
\hline $\begin{array}{l}\text { wavenumber } \\
\left(\mathrm{cm}^{-1}\right)\end{array}$ & vibrations & references \\
\hline 3650,3624 & $\mathrm{OH}$ stretching vibrations & $\begin{array}{l}\text { Baron et al., 2016; Mano et al., 2014; } \\
\text { Christidis and Mitsis, 2006; Petit, 2005; } \\
\text { Gerard and Herbillon, 1983; Wilkins and Ito, } \\
\text { 1967; Madejová et al., } 2011\end{array}$ \\
\hline 3420 & $\begin{array}{l}\text { OH stretching vibrations of } \\
\text { adsorbed water }\end{array}$ & Madejová et al., 2011; \\
\hline 710 & $\mathrm{OH}$ bending & $\begin{array}{l}\text { Madejová et al., 2011 ; Petit et al., 2008 } \\
\text { Baron et al., 2016; Mano et al., 2014; } \\
\text { Christidis and Mitsis, 2006; Petit, 2005; } \\
\text { Gerard and Herbillon, 1983; Wilkins and Ito, } \\
\text { 1967 }\end{array}$ \\
\hline 660 & $\mathrm{OH}$ bending and $\mathrm{Si}-\mathrm{O}$ & Madejová et al., 2011 ; Petit et al., 2008 \\
\hline 870 and 820 & $\mathrm{OH}$ bending vibrations & $\begin{array}{l}\text { Farmer, 1974; Petit et al., } 2002 \text { and Mano et } \\
\text { al., } 2014\end{array}$ \\
\hline $\begin{array}{c}1020,950 \text { and } \\
790\end{array}$ & $\begin{array}{l}\text { Si-O stretching vibration } \\
\text { before reduction at } 770^{\circ} \mathrm{C}\end{array}$ & adejová et al., 1998 ; Ptáček \\
\hline 1090 & $\begin{array}{l}\text { Si-O stretching vibration after } \\
\text { reduction at } 770^{\circ} \mathrm{C}\end{array}$ & et al., 2013 \\
\hline
\end{tabular}




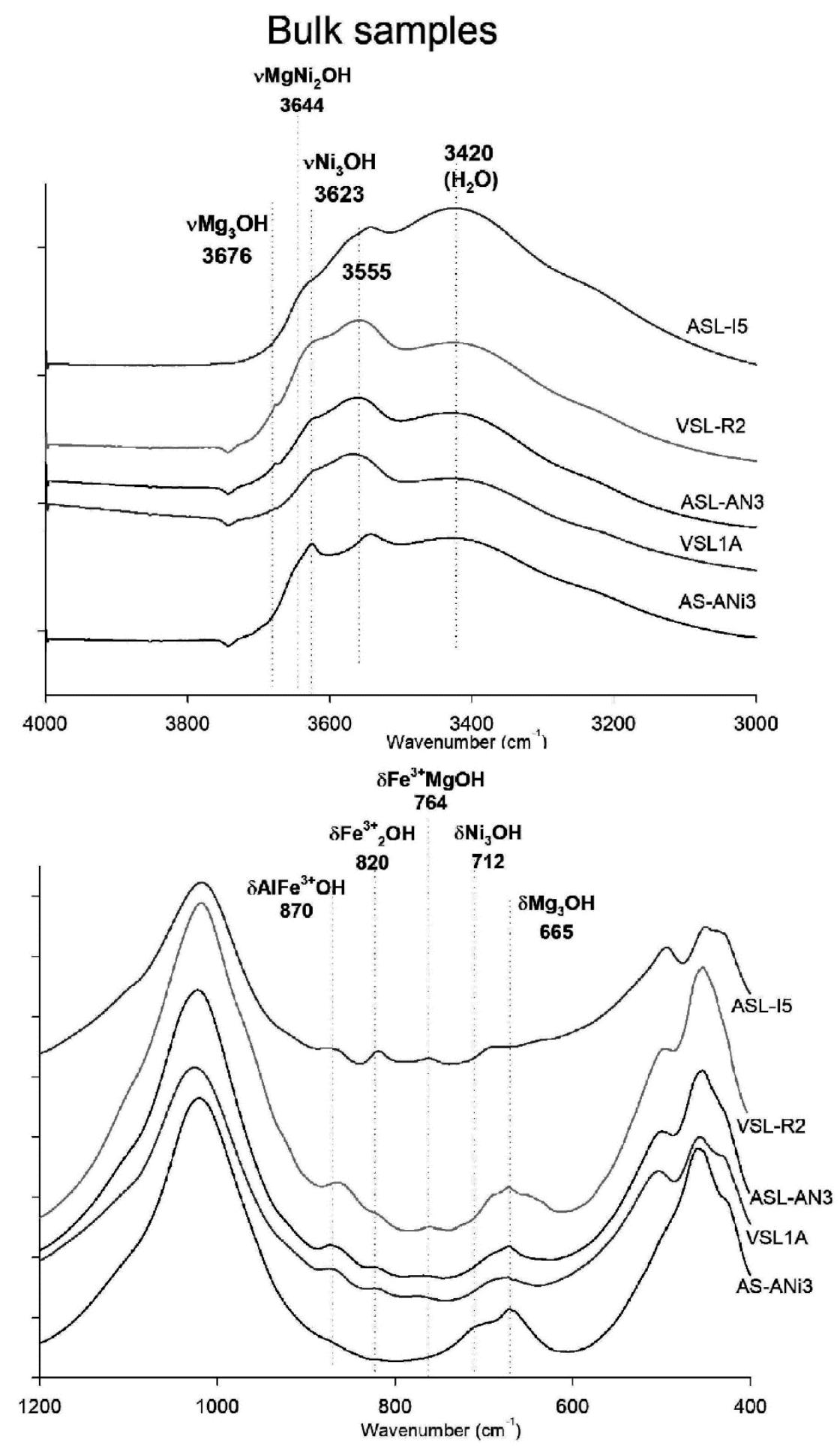

Figure 9 - MIR spectra of the bulk samples, showing the effect of changing cations replacements ( $\mathrm{Fe}, \mathrm{Al}, \mathrm{Ni}$ and $\mathrm{Mg}$ ) on the absorption bands 


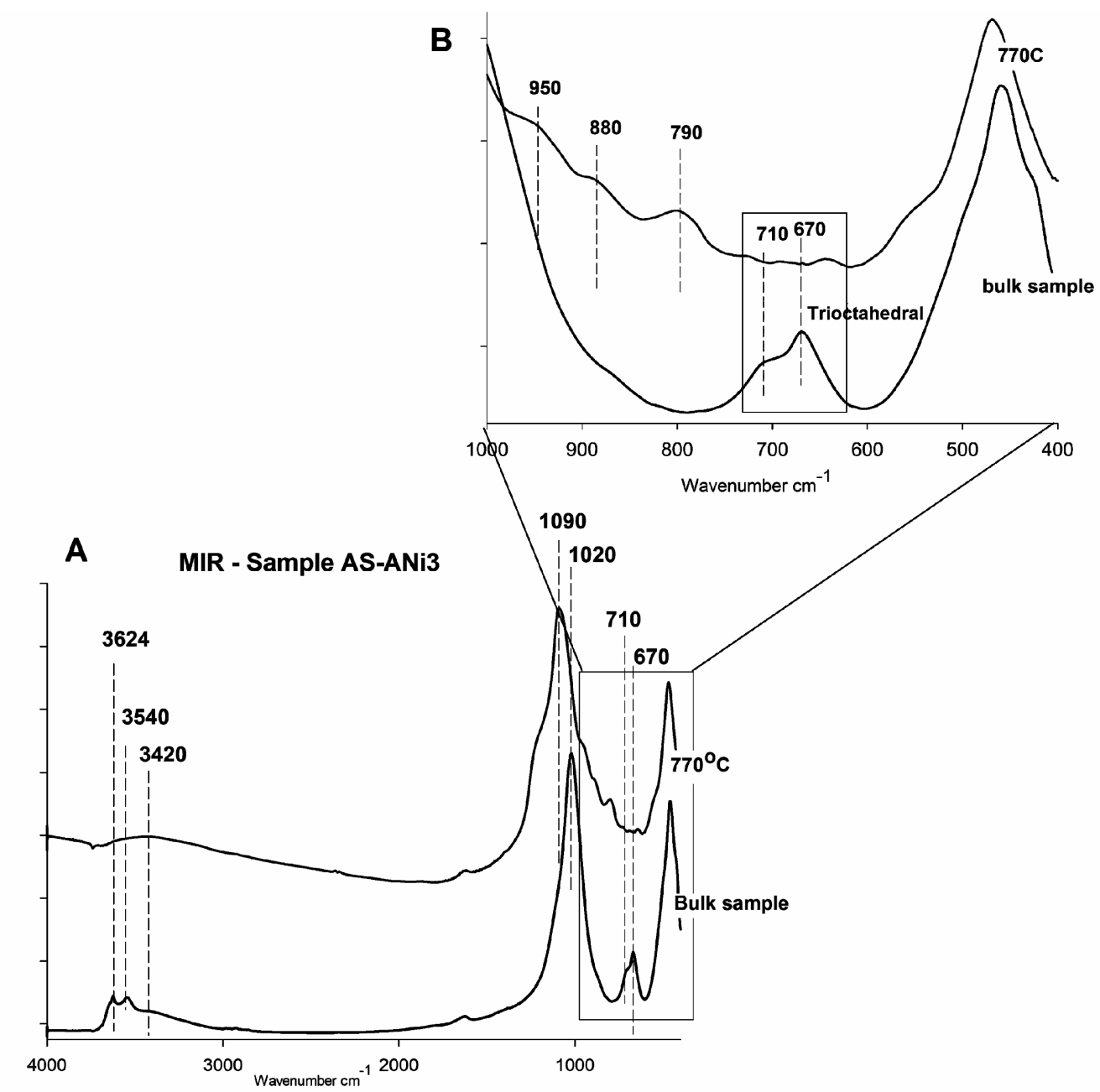

Figure 10 - MIR spectra of sample AS-ANi3 bulk sample and after the reduction step (A). B shows detail of the $\mathrm{O}-\mathrm{H}$ bending region.

For the bulk samples (Figure 9), the trioctahedral character is revealed by absorption bands at 3650,3624 and $710 \mathrm{~cm}^{-1}$, assigned to $\mathrm{vMg}_{3} \mathrm{OH}, v \mathrm{Ni}_{3} \mathrm{OH}$ and $\delta \mathrm{Ni}_{3} \mathrm{OH}$ modes, respectively (Wilkins and Ito, 1967; Gerard and Herbillon, 1983; Petit, 2005; Christidis and Mitsis, 2006; Mano et al., 2014; Baron et al., 2016). The adsorbed water is assigned to the absorption band at $3420 \mathrm{~cm}^{-1}$ (Madejová et al., 2011). For the dioctahedral smectites, in the $\mathrm{OH}$-bending region, the absorption band at $870 \mathrm{~cm}^{-1}$ is assigned to the $\delta \mathrm{AlFe}^{3+} \mathrm{OH}$ mode and the band of $820 \mathrm{~cm}^{-1}$, to the $\delta \mathrm{Fe}^{3+} \mathrm{Fe}^{3+} \mathrm{OH}$ mode (Farmer, 1974; Petit et al., 2002 and Mano et al., 2014). The band at $660 \mathrm{~cm}^{-1}$ is also characteristic of trioctahedral smectites and assigned to the $\delta \mathrm{Mg}_{3} \mathrm{OH}$ mode (Petit et al., 2008; Madejová et al., 2011). 
Minor clay mineral structural modifications can be noted by FTIR spectroscopy (Madejová, 2003; Pálková et al., 2003). Mid-infrared (MIR) spectra of sample ASANi3, performed before and after the roasting step, are shown in Figure 10. After the reduction step at $770^{\circ} \mathrm{C}$, the absorption bands attributed to $\mathrm{OH}$-stretching modes disappeared. The absorption band at $1020 \mathrm{~cm}^{-1}$, attributed to Si-O stretching vibrations in tetrahedral sheets of layer silicates, shifted to $1090 \mathrm{~cm}^{-1}$ after the reduction step. This band, together with new bands at $950 \mathrm{~cm}^{-1}$ and 790 $\mathrm{cm}^{-1}$ (Figure 10) suggest the presence of amorphous silica (Madejová et al., 1998; Liu et al., 2014) that can be formed during the roasting step.

\subsection{Nickel extraction}

The nickel extractions, expressed as the percentage of the nickel extracted over the total nickel in each sample, after roasting at the different temperatures and leaching steps are presented in Figure 11.

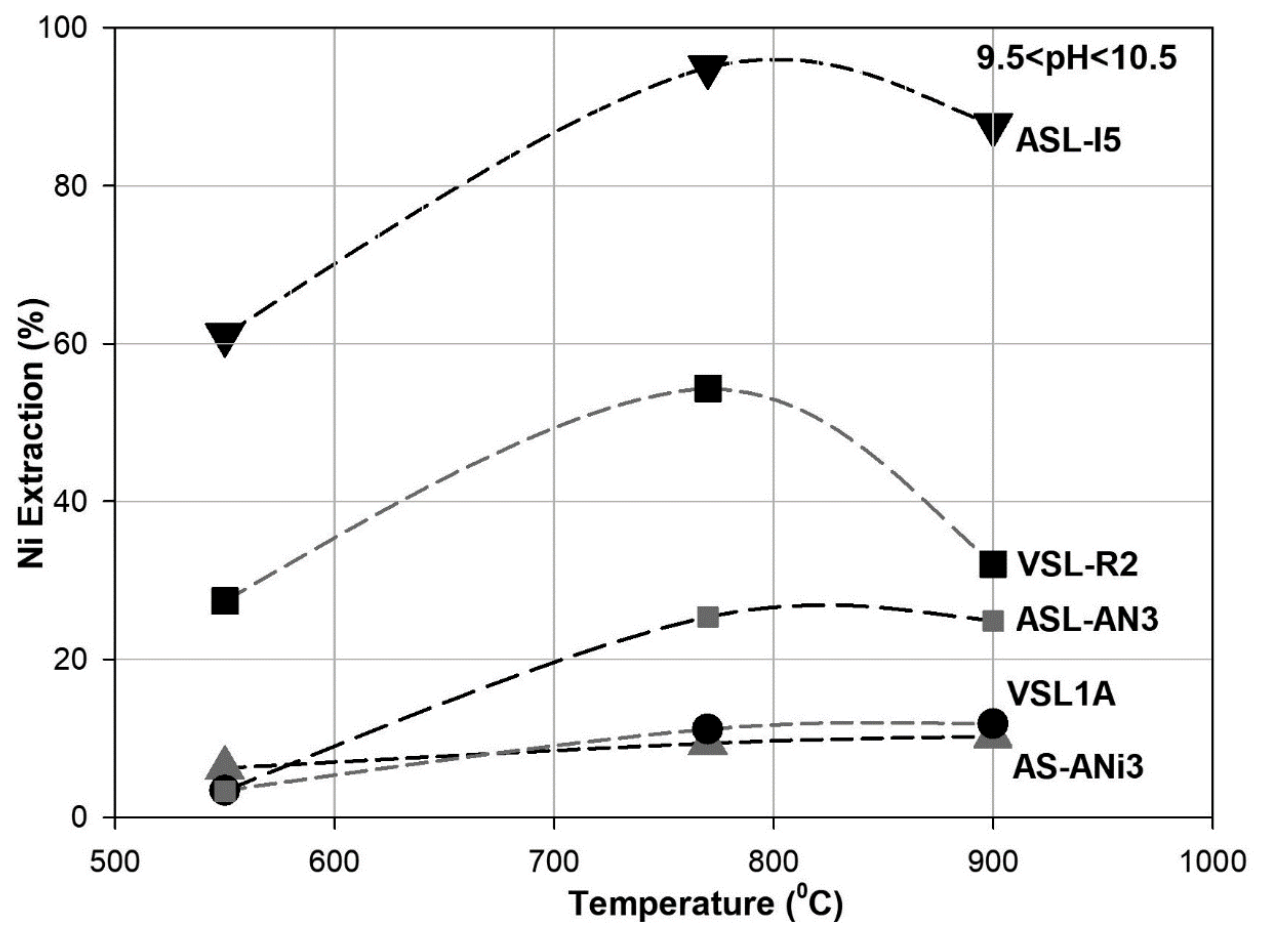

Figure 11 - Nickel extraction after different temperatures. The leaching conditions were the same for all the samples: $\mathrm{pH}$ between 9.5 to 10.5 , temperature $<50^{\circ} \mathrm{C}, 120$ min of leaching time. 
A remarkable nickel recovery, with greater than $90 \%$ of the total nickel extracted, was observed for sample ASL-15 (dioctahedral smectite) after reduction roasting at $770^{\circ} \mathrm{C}$ (Figure 11). By contrast, less than $10 \%$ of the total nickel was extracted from sample AS-ANi3 (trioctahedral smectite), which exhibited low and near constant nickel extraction, regardless of the roasting temperature. Sample VSLR2 exhibited over $50 \%$ nickel extraction after reduction roasting at $770^{\circ} \mathrm{C}$. The nickel extraction for samples VSL1A and ASL-AN3 did not reach $30 \%$ after reduction roasting at $770^{\circ} \mathrm{C}$.

The best nickel extractions were obtained for the samples reduced at approximately $700-800^{\circ} \mathrm{C}$. A substantial drop in nickel extractions was observed especially for samples ASL-15 and VSL-R2 at temperatures higher than 770$800^{\circ} \mathrm{C}$.

\section{Discussion}

Nickel laterites, depending upon their mineralogical composition, are processed by either hydrometallurgical or pyrometallurgical process. Canterford (1975), De Graaf (1980), Dalvi et al. (2004), suggested that nickel silicate ores are better suitable for pyrometallurgical processing, and limonitic ores for hydrometallurgical processing. Apostolidis and Distin (1978), De Graaf (1979) and Chander and Sharma (1981) pointed out that nickel extractions are intrinsically related to the iron and nickel metallic phases formed during the roasting and leaching steps. Nickel extraction reaches a maximum when it combines with iron as (Ni-Fe)O (Chander and Sharma, 1981). This phase is probably formed nearly $700^{\circ} \mathrm{C}$ (for limonitic ore) in which iron is partially reduced and most of the nickel is reduced. Chander and Sharma (1981) explained that at 
higher temperatures $\left(>800^{\circ} \mathrm{C}\right)$, nickel can be trapped into the neoformed phases, decreasing nickel extractions values. Apostolidis and Distin (1978) showed that nickel is properly leached from the Fe-Ni alloy, whereas the extraction is slow and incomplete from the olivines.

The Fe-rich dioctahedral smectite from Niquelândia gave nearly $90 \%$ of nickel extraction; in turn, for the trioctahedral smectite, the nickel extraction did not exceed $10 \%$, despite the higher nickel content. Iron-rich phases, such as spinels and Fe-Ni alloy, were formed from the Fe-rich dioctahedral smectite, during the roasting reduction step, according to XRD analysis. In turn, pyroxene, talc and olivine were formed from the trioctahedral smectite.

De Graaf (1979) described a graph, which although considered a gross simplification of $\mathrm{Fe}-\mathrm{O}$ and $\mathrm{Ni}-\mathrm{O}$ systems, is useful to predict nickel extraction behaviour, based on the newly formed phases. For example, De Graaf explained that for limonitic ore, the optimum nickel extraction is obtained in the "wustite" zone; however, for silicate ore, the maximum extraction can be reached in the "magnetite/wustite" zone. To account for the formation of these phases, Elliott et al., (2016), presented the reactions:

$$
\begin{gathered}
2 \mathrm{FeOOH} \text { (goethite) } \rightarrow \mathrm{Fe}_{2} \mathrm{O}_{3} \text { (hematite) }+\mathrm{H}_{2} \mathrm{O} \\
6(\mathrm{Fe}, \mathrm{Ni}) \mathrm{OOH} \text { (goethite) } \rightarrow 2(\mathrm{Ni}, \mathrm{Fe})_{3} \mathrm{O}_{4} \text { (spinel) }+3 \mathrm{H}_{2} \mathrm{O}+1 / 2 \mathrm{O}_{2} \\
3 \mathrm{Fe}_{2} \mathrm{O}_{3} \text { (hematite) }+\mathrm{CO} \rightarrow 2 \mathrm{Fe}_{3} \mathrm{O}_{4} \text { (magnetite) }+\mathrm{CO}_{2} \\
\mathrm{Fe}_{3} \mathrm{O}_{4} \text { (magnetite) }+\mathrm{CO} \rightarrow 3 \mathrm{FeO} \text { (wustite) }+\mathrm{CO}_{2} \\
\mathrm{FeO} \text { (wustite) }+\mathrm{CO} \rightarrow \mathrm{Fe}+\mathrm{CO}_{2}
\end{gathered}
$$

Some of the reactions above were also described by Wang et al. (2017) as intermediates in the formation of Fe-Ni alloys. They also presented the standard 
Gibbs free energy for some of these reactions. Wang et al. (2017) explained that it is easy to transform $\mathrm{Fe}_{3} \mathrm{O}_{4}$ to $\mathrm{FeO}$ at temperatures higher than $973 \mathrm{~K}\left(700^{\circ} \mathrm{C}\right)$. Based on the XRD results from samples ASL-15 and AS-ANi3, the following reactions were indicated:

$$
\begin{aligned}
& \mathrm{Fe}_{2} \mathrm{Si}_{4} \mathrm{O}_{10}(\mathrm{OH})_{2} \text { (dioctahedral smectite) }+2 \mathrm{Fe}_{2} \mathrm{O}_{3}(\text { hem })+(\mathrm{Fe}, \mathrm{Mg}) \mathrm{Al}_{2} \mathrm{O}_{4}(\text { spinel })+ \\
& 2\left(\mathrm{Mg}, \mathrm{Ni}_{3}\right)_{3} \mathrm{Si}_{4} \mathrm{O}_{10}(\mathrm{OH})_{2}\left(\text { talc) } \rightarrow 2 \mathrm{Mg}_{2} \mathrm{SiO}_{4} \text { (oliv) }+(\mathrm{Fe}, \mathrm{Mg})_{2} \mathrm{Si}_{2} \mathrm{O}_{6} \text { (pyrox) }+\mathrm{MgAl}_{2} \mathrm{O}_{4}\right. \\
& \text { (spinel) }+\mathrm{Fe}^{3+}{ }_{2} \mathrm{Fe}^{2+} \mathrm{O}_{4} \text { (magn) }+2 \mathrm{FeNi}_{3}+8 \mathrm{SiO}_{2}+3 \mathrm{H}_{2} \mathrm{O}+{ }^{5} / 2 \mathrm{O}_{2}
\end{aligned}
$$

and

$(\mathrm{Ni}, \mathrm{Mg})_{3} \mathrm{Si}_{4} \mathrm{O}_{10}(\mathrm{OH})_{2}$ (trioctahedral smectite) $+\left(\mathrm{Mg}, \mathrm{Ni}_{3} \mathrm{Si}_{4} \mathrm{O}_{10}(\mathrm{OH})_{2}(\right.$ talc $)+$

$(\mathrm{Ni}, \mathrm{Mg})_{2} \mathrm{Si}_{2} \mathrm{O}_{6}$ (pyrox) $+(\mathrm{Fe}, \mathrm{Al})_{2} \mathrm{O}_{4}($ spinel $) \rightarrow 2\left(\mathrm{Mg}, \mathrm{Ni}_{3}\right)_{3} \mathrm{Si}_{4} \mathrm{O}_{10}(\mathrm{OH})_{2}($ talc $)+$

$$
(\mathrm{Fe}, \mathrm{Al})_{2} \mathrm{O}_{4}\left(\text { spinel) }+(\mathrm{Ni}, \mathrm{Mg})_{2} \mathrm{Si}_{2} \mathrm{O}_{6}\right. \text { (pyrox) }
$$

Due to the low iron content in the AS-ANi3 sample, nickel did not report to ironbearing phases but was rather trapped in the structure of neoformed silicates. De Graaf (1980), deduced that nickel was trapped in the silicates phases by attacking the silicate ore residue with a strong acid $\mathrm{HCl}+(\mathrm{NH} 4 \mathrm{~F})$, increasing the nickel extraction from $70 \%$ to $100 \%$.

The iron/nickel ratio can explain the nickel extraction results for the others samples. Iron-nickel alloys formed during the reduction roasting step are attacked by ammoniacal solutions. Sample VSL1A (Figures 11 and 5), despite forming Fe$\mathrm{Ni}$ alloy at $770^{\circ} \mathrm{C}$, exhibited a poor nickel extraction (nearly $10 \%$ of $\mathrm{Ni}$ ); due to the lower Fe/Ni ratio (1.5). Conversely, sample VSL-R2 (Fe/Ni ratio $\approx$ ) showed nickel extractions close to 55\%; compared with samples VSL1A and ASL-AN3. The leached Fe-Ni alloy was higher in this sample than the two others (Figure 5). Finally, sample ASL-AN3 exhibited an intermediate nickel extraction, of nearly 
25\%; and also, an intermediate $\mathrm{Fe} / \mathrm{Ni}$ ratio. The reaction concerning these newly formed phases as suggested from the XRD results is:

$(\mathrm{Ni}, \mathrm{Fe})_{3} \mathrm{Si}_{4} \mathrm{O}_{10}(\mathrm{OH})_{2}$ (trioctahedral smectite) $+\mathrm{Fe}_{2} \mathrm{Si}_{4} \mathrm{O}_{10}(\mathrm{OH})_{2}$ (dioctahedral smectite) + $(\mathrm{Ni}, \mathrm{Mg})_{2} \mathrm{Si}_{2} \mathrm{O}_{6}$ (pyrox) $+(\mathrm{Fe}, \mathrm{Al})_{2} \mathrm{O}_{4}$ (spinel) $\rightarrow\left(\mathrm{Ni}, \mathrm{Mg}_{2} \mathrm{Si}_{2} \mathrm{O}_{6}\right.$ (pyrox) $+2 \mathrm{Fe}_{2} \mathrm{O}_{3}($ hem $)+$ $\mathrm{FeNi}_{3}+(\mathrm{Fe}, \mathrm{Al})_{2} \mathrm{O}_{4}$ (spinel) $+8 \mathrm{SiO}_{2}+2 \mathrm{H}_{2} \mathrm{O}$

The XRD results suggest that, if a Fe-rich mineral (e.g. goethite) was added to the Ni-rich smectite ore, perhaps the nickel may combine with reduced iron to form Fe-Ni alloys, resulting in better nickel extractions. Indeed, Canterford (1975) reported that Davidson (1972) added ferric oxide to high-magnesia silicate ores, improving the nickel extraction by $20 \%$. However, Canterford also mentioned another research conducted by Scott and Dyson in which ferric oxide was added to their sample, but did not give any improvement.

\section{Conclusions}

In the Caron process, the composition of the mineralogical assemblage and the reducing atmosphere, carried out during the roasting reduction step, are essential parameters to induce the formation of new Fe-Ni phases. In samples, in which there was no Fe-Ni alloy or low Fe/Ni ratio (<1.5), the nickel extraction was poor $\left(<10 \%\right.$ at $\left.770^{\circ} \mathrm{C}\right)$. Thereby, only the nickel from the Ni-Fe alloys were solubilized by ammoniacal leaching. In addition, the nickel losses were also due to drops of Fe-Ni alloys, being trapped within silicate phases, which were not leached by the ammoniacal solutions.

The nickel extraction data showed that the optimal reduction roasting temperature to obtain the best nickel extractions was $770^{\circ} \mathrm{C}$. Temperatures higher than $800^{\circ} \mathrm{C}$ caused a decrease in nickel extraction as new silicate minerals, such as pyroxenes and olivines, not solubilized by ammoniacal 
solutions, were formed. These neoformed minerals which are more resistant to leaching can trap Ni-Fe alloys within their particle structure and/or host nickel within their crystal structures.

In spite of all the studies previously conducted, the mechanisms for the formation of neoformed minerals are not fully understood, and further studies varying chemical compositions on the feed and redox atmosphere should be performed.

\section{Acknowledgments}

This study has been supported by CAPES - Coordenação de Aperfeiçoamento de Pessoal de Nível Superior/ Brazilian Coordination for the Improvement of Higher Education Personnel [Project CAPES/COFECUB: 9075/12-7 - Te 761/12] and FAPESP - Fundação de Apoio à Pesquisa do Estado de São Paulo/ the State of São Paulo Research Foundation [Project: 10/50849-4]. The authors also thank

Eng. Marco Antonio Angora, Héctor Nelson E. Troncoso and Bianca Foggiatto; Votorantim Metais Níquel Company for all the contributions and Professor Danilo Rheinheimer dos Santos from the Universidade Federal de Santa Maria. The authors are very grateful to the reviewers and to the editor in chief of the Hydrometallurgical Journal who greatly helped us to improve this article.

References:

Apostolidis, C.I. and Distin, P.A. 1978. The kinetics of the sulphuric acid leaching of nickel and magnesium from reduction roasted serpentine. Hydrometallurgy. 3, 181-196.

Arab, P.B., Araújo, T.P. and Pejon, O.J.. 2015. Identification of clay minerals in mixtures subjected to differential thermal and thermogravimetry analyses and methylene blue adsorption tests. Applied Clay Science. 114, 133-14.

Baron, F., Petit, S., 2016. Interpretation of the infrared spectra of the lizardite-nepouite series in the near-and mid-infrared range. American Mineralogist. 101, 423-430. 
Baron, F., Pushparaj, S.S.C., Fontaine, C., Sivaiah, M.V., Decarreau, A., Petit, S., 2016. Microwave-assisted hydrothermal synthesis of Ni-Mg layered silicate clays. Current Microwave Chemistry. 3, 85-89.

Boldt Jr, J.R. 1967. The winning of nickel, its geology, mining and extractive metallurgy. Van Nostrand Company. 487 p.

Brigatti, M.F. 1983. Relationships between composition and structure in Fe-rich smectites. Clay Minerals. 18, 177-186.

Bunjaku, A., 2013. The effect of mineralogy, sulphur, and reducing gases on the reducibility of saprolitic nickel ores. Doctoral dissertations. Aalto University School of Chemical Technology, $48 \mathrm{p}$.

Canterford, J.H. 1975. The treatment of nickeliferous laterites. Minerals Science and Engineering. 7, 1, 3-17.

Chander, S. and Sharma, V.N. 1981. Reduction roasting/ammonia leaching of nickeliferous laterites. Hydrometallurgy. 7, 315-327.

Christidis, G.E. and Mitsis, I., 2006. A new Ni-rich stevensite from the ophiolite complex of Othrys, Central Greece. Clays and Clay Minerals. 54, 653-666.

Colin, F., Nahon, D., Trescases, J.J., Melfi, A.J., 1990. Lateritic weathering of pyroxenites at Niquelândia, Goias, Brazil: The supergene behavior of nickel. Economic Geology. 85, 1010-1023.

Cornell, R.M. and Schwertmann, U. 2003. The iron oxides Structure, Properties, Reactions, Occurrence and Uses. VCH, Weinheim. 642 p.

Dalvi, A., Bacon, G. and Osborne, R. 2004. The past and the future of nickel laterites. In: PDAC 2004 International convention, Toronto, Canada. Trade show and investors exchange. Toronto: Prospectors and Developers Association of Canada, 7-10.

De Graaf, J. E., 1979. The treatment of lateritic nickel ores - a further study of the Caron process and other possible improvements: Part I. effect of reduction conditions. Hydrometallurgy. 5, 47- 65.

De Graaf, J. E., 1980. The treatment of lateritic nickel ores - a further study of the Caron process and other possible improvements: Part II. Leaching studies. Hydrometallurgy. 5, 255-271.

Diaz, M.C., Landolt, C.A., Vahed, A., Warner, A.E.M. and Taylor, J.C. 1988. A review of nickel pyrometallurgical operations. Journal of Metals. 40, 9, 28-33.

Elliott, R., Pickles, C.A. and Forster, J. 2016. Thermodynamics of the reduction roasting of nickeliferous laterite ores. Journal of Minerals and Materials Characterization and Engineering. 4, 320-346.

Farmer, V.C. 1974. Infrared Spectra of Minerals. Monograph 4, The Mineralogical Society, London. 
Frost, R.L., Kloprogge, J.T. and Ding, Z. 2002. The Garfield and Uley nontronites -an infrared spectroscopic comparison. Spectrochimica Acta Part A. 58, 1881- 1894.

Gaudin, A., Grauby, O., Noack, Y., Decarreau, A. and Petit, S. 2004. Accurate crystal chemistry of ferric smectites from the lateritic nickel ore of Murrin Murrin (Western Australia). I. XRD and multi-scale chemical approaches. Clay Minerals. 39, 301-315.

Gerard, P. and Herbillon, A.J., 1983. Infrared studies of Ni-bearing clay minerals of the kerolite-pimelite series. Clays and Clay Minerals. 31, 143-151.

Liu, X., Liu, X. and Hu, Y.. 2014. Investigation of the thermal decomposition of talc. Clays and Clay Minerals. 62, 2, 137-144.

Madejová, J., 2003. Review: FTIR techniques in clay mineral studies. Vibrational spectroscopy. 31, 1-10.

Madejová, J., Bujdak, J., Janek, M. and Komadel, P., 1998. Comparative FT-IR study of the structural modifications during acid treatment of dioctahedral smectites and hectorite. Spectrochimica. Acta Part A 54, 1397-1406.

Madejová, J., Balan, E. and Petit, S., 2011. Application of vibrational spectrocopy to the characterization of phyllosilicates and other industrial minerals. In: Christidis, G. E. (Ed.). Advances in the characterization of industrial minerals. Middlesex: European Mineralogical Union/Mineralogical Society of Great Britain and Ireland (EMU Notes in Mineralogy). 9, 6, 171-226.

Mano, E. S., Caner L., Petit, S., Chaves A. P. and Mexias A.S., 2014. Mineralogical characterization of Ni-bearing smectites from Niquelândia, Brazil. Clays and Clay Minerals. 62, 4, 324-335.

Moore, D.M. and Reynolds, R.C. Jr. (1997) X-ray Diffraction and the Identification and Analysis of Clay Minerals. Oxford University Press, New York.

Oliveira, S. M. B. de; Trescases, J.J. and Melfi, A.J., 1992. Lateritic nickel deposits of Brazil. Mineralium Deposita. 27, 137-146.

O'Connor, F., Cheung, W.H. and Valix, M. 2006. Reduction roasting of limonite ores: effect of dehydroxylation. International Journal of Mineral Processing. 80. 88-99.

Pálková, H., Madejova, J. and Righi, D., 2003. Acid dissolution of reduced-charge Li- and Ni-montmorillonites. Clays and Clay Minerals. 51, 2, 133-142.

Petit, S., 2005. Crystal-chemistry of talcs: a NIR and MIR spectroscopic approach. In: Kloprogge, J.T. (Ed.), The Application of Vibrational Spectroscopy to Clay Minerals and Layered Double Hydroxides: CMS Workshop Lectures, Aurora, Colorado. 13, 41-64.

Petit S., Caillaud J., Righi D., Madejová J., Elsass F. and Köster H.M. 2002. Characterization and crystal chemistry of an Fe-rich montmorillonite from Ölberg, Germany. Clay Minerals. 37, 283-297.

Petit, S., Righi, D. and Decarreau, A. 2008. Transformation of synthetic Zn-stevensite to Zntalc induced by the Hofmann-Klemen effect. Clays and Clay Minerals. 56, 6, 645-654. 
Ptáček, P., Opravil, T., Šoukal, F., Havlica, J., Másilko, J. and Wasserbauer, J.. 2013. Preparation of dehydroxylated and delaminated talc: Meta-talc. Ceramics International. 39, 9055-9061.

Rhamdhani, M. A., Hayes, P.C. and Jak, E., 2009a. Nickel laterite Part 2 - thermodynamic analysis of phase transformations occurring during reduction roasting. Mineral Processing and Extractive Metallurgy. 118, 3, 146-155.

Rhamdhani, M. A., Chen, J., Hidayat, T., Jak, E. and Hayes, P. 2009b. Advances in research on nickel production through the Caron process. Proceedings of European Metallurgical Conference - EMC. 3, 899-913.

Rice, N. M. 2016. A hydrochloric acid process for nickeliferous laterites. Minerals Engineering. 88, 28-52.

Trescases, J. J., Melfi, A. J. and Oliveira, S. M. B. de, 1981. Nickeliferous laterites of Brazil. In: Laterisation Processes, Proceedings of International Seminar of Laterisation Processes, Tivandrum, India, 1979. 170-184.

Valix, M. and Cheung, W.H., 2002. Study of phase transformation of laterite ores at high temperature. Minerals Engineering. 15, 607-612.

Wang, Z.; Chu, M.; Liu, Z.; Wang, H.; Zhao, W. and Gao, L. 2017. Preparing ferro-nickel alloy from low-grade laterite nickel ore based on metallized reduction-magnetic separation. Metals. 7, 313, 1-14.

Wilkins, R.W.T. and Ito, J., 1967. Infrared spectra of some synthetic talcs. The American Mineralogist. 52, 1649-1661. 